\title{
EFFECT OF FEED RESTRICTION ON GROWTH PERFORMANCE, SUDDEN DEATH SYNDROME AND SOME BLOOD PARAMETERS IN BROILER CHICKENS
}

\author{
ELDSOKEY NASSEF ; MUSTAFA SHUKRY ${ }^{* *}$ and TAREK KAMAL ${ }^{* * *}$ \\ * Department of Nutrition and Clinical Nutrition, Faculty of Veterinary Medicine, Kafrelsheikh University, Egypt. \\ *** Department of Physiology, Faculty of Veterinary Medicine, Kafrelsheikh University, Egypt. \\ ${ }^{* * *}$ Department of Biochemistry, Faculty of Veterinary Medicine, Kafrelsheikh University, Egypt.
}

Email: dsokeynassef@yahoo.com

Assiut University web-site: www.aun.edu.eg

\section{ABSTRACT}

Received at: 28/9/2015

Accepted: 30/10/2015
The study aimed to determine the effects of feed restriction on growth, feed efficiency, sudden death syndrome (SDS) and some blood parameters in broilers. One hundred mixed sex chicks (Avian 48) were randomly allocated into two treatment groups each of 50 chicks (5 replicates). Broilers in the first treatment fed ad libitum until the end of the experiment ( 35 days of age), while feeds in the other treatment were restricted by $20 \%$ from 7 to 21 days. Broilers fed ad- libitum had significantly high body weight gain, better feed conversion and high mortality rate compared with the restricted broilers. Although the mortality rate was significantly higher in ad libitum fed broilers, their better feed efficiency significantly rise the income over feed cost (IOFC). Feed restriction lowered serum lipids and triglycerides associated with macrocytic anemia. Inconclusion, feed restriction negatively affected growth performance, blood parameters and IOFC. Therefore, results support ad libitum feeding for broiler chickens.

Key words: Broilers, Feed restriction, Performance, Blood parameters, Sudden death syndrome.

\section{INTRODUCTION}

Continuous genetic selection and improvement in nutrition have led to a very fast growth rate in modern strains of broiler chickens. Metabolic disorders such as ascites, sudden death syndrome (SDS) and leg problems are related to a rapid early growth rate in poultry, especially in broilers and their incidence can be decreased by slowing early growth.

The feed restriction programs is one of the main techniques in growth curve manipulation for increasing production efficiency and decreasing the unfavorable effects of fast growth rate in broiler chicken production industry and could be profitable in broiler chickens production efficiency (Sahraei, 2014). Early feed restriction programs rely on phenomenon called compensatory growth or catch up growth to produce market body weight similar to control group. Compensatory growth is defined as a rapid growth after a period of nutritional deprivation. Physical feed restriction is one of the common procedure used to control feed intake in poultry. It is applied by supplying a calculated amount of feed per bird per day (Plavnik and Hurwitz, 1989).
Sudden death syndrome has been reported in most areas of the world that raise broilers intensively. Young, healthy, fast-growing broiler chickens die suddenly with a short, terminal, wing-beating convulsion. Many affected broilers just "flip over" and die on their backs. Feeding, climate, rearing technique, physiological state, age, sex and genotype can influence the level of a particular blood constituent (Meluzzi et al., 1992).

There is less information regarding the effects of feed restriction on feed efficiency, some blood parameters, SDS and lipids profile. Therefore the first aim of this study was to determine the effects of feed restriction during the period from 7 to $21 \mathrm{~d}$ on growth, feed efficiency and incidence of SDS. The second aim was to determine the effects of feed restriction on some blood parameters, liver enzymes and lipids profile in broilers.

\section{MATERIALS and METHODS}

\section{Birds and diets}

One hundred mixed sex chicks (Avian 48), obtained from the local hatchery (Abdel Salam Hegazi, Tanta, 
Egypt), were randomly allocated into two treatment groups, each of 50 chicks. Each treatment was subdivided into 5replicates, each of 10 chicks, located in floor pens of $100 \times 120 \mathrm{~cm}$ width $\mathrm{x}$ length. Broilers in the first treatment fed ad libitum until the end of the experiment ( 35 days of age), while in the other treatment, broilers fed ad libitum till 7 days of age, then were physically restricted of feed by $20 \%$ from 7 to 21 days and again fed ad libitum until the end of the experiment (re-feeding period, from 22 to 35 days). According to the manual of broilers strain, feed restriction was applied by supplying a calculated amount of feed ( $80 \%$ of ad libitum feeding) per bird per day (Plavnik and Hurwitz, 1989). Each pen had woods havings litter, one drinker and one hanging suspended feeder.
Diets were formulated according to nutrient specifications of broiler strain manual. Broilers were fed pelleted starter diet from 1 to 14 days of age ( $\mathrm{ME}=3084 \mathrm{kcal} / \mathrm{kg}$ and $22.9 \%$ crude protein), grower diet from 15 to 28 days of age ( $\mathrm{ME}=3151 \mathrm{kcal} / \mathrm{kg}$ and $20 \%$ crude protein) and finisher diet from 29 to 35 days $(\mathrm{ME}=3160 \mathrm{kcal} / \mathrm{kg}$ and $18.5 \%$ crude protein). Composition of diets for starter, grower and finisher periods was presented in Table 1. Broilers were provided with continuous light, while temperature was $32^{\circ} \mathrm{C}$ at the first week then gradually lowered to average $25^{\circ} \mathrm{C}$ and this temperature was maintained to marketing age. Broilers were vaccinated against Newcastle disease (7 and 14 days); against infectious bronchitis (1 day); and against infectious bursal disease (12 and 18 days).

Table 1: Physical and chemical composition of the diets.

\begin{tabular}{lccc}
\hline Physical composition (\%) & Starter & Grower & Finisher \\
\hline Yellow corn grain & 55.25 & 64.4 & 67.05 \\
\hline Soybean meal (48\%) & 32 & 17 & 14.55 \\
\hline Full fat soybean & - & 10 & 12 \\
\hline Corn gluten meal & 6 & 4 & 1 \\
\hline Soya oil & 2.5 & 1 & 1.2 \\
\hline Limestone & 1.4 & 1.2 & 1.3 \\
\hline Dicalcium phosphate & 1.8 & 1.5 & 0.3 \\
\hline Salt & 0.35 & 0.3 & 0.3 \\
\hline Vitamin-mineral premix* & 0.3 & 0.3 & 0.1 \\
\hline L-lysine & 0.25 & 0.2 & 3160 \\
\hline D,L-methionine & 0.15 & 0.1 & 90.28 \\
\hline Chemical composition & & & 18.48 \\
\hline Metabolizable energy $(\mathrm{kcal} / \mathrm{kg})$ & 3084 & 3151 & 5.65 \\
\hline Dry matter \% & 90.12 & 90.25 & 6.38 \\
\hline Crude protein \% & 22.91 & 19.94 & 5.21 \\
\hline Ether extract \% & 5.11 & 5.32 & 6.54 \\
\hline Ash \% & 7.23 & 5.20 & \\
\hline Acid detergent fiber \% & 5.08 & & \\
\hline
\end{tabular}

* Supplied per kilogram of diet: vitamin A, 12000 IU (retinylpalmitate); cholecalciferol, 5000 IU; vitamin E, 60 IU (dl-a-tocopheryl acetate); vitamin $\mathrm{K}, 3.0 \mathrm{mg}$; thiamin, $2.0 \mathrm{mg}$; riboflavin, $8.0 \mathrm{mg}$; pantothenic acid, $12.0 \mathrm{mg}$; pyridoxine, $4.0 \mathrm{mg}$; biotin, $0.2 \mathrm{mg}$; vitamin B12, $15 \mathrm{ug}$; niacin, $50 \mathrm{mg}$; choline, $400 \mathrm{mg}$; folic acid, $2.0 \mathrm{mg}$; manganese, $100 \mathrm{mg}$; zinc, $100 \mathrm{mg}$; copper, $15 \mathrm{mg}$; iron, $40 \mathrm{mg}$; and selenium, $0.3 \mathrm{mg}$.

\section{Measurements}

All broilers were weighed at the beginning and at the end of the experiment. Body weight gain was calculated as the difference between the final and the initial weight. Feed intake was recorded daily and calculated at the end of the experiment. Feed conversion ratio was calculated as feed to gain ratio.

All dead broilers were recorded daily. Broilers dead with SDS were recorded separately from others. Sudden death syndrome was suspected in well grown and healthy-looking broilers, died suddenly with a short terminal wing-beating convulsion or found dead on their backs or breasts. Diagnosis was supported by necropsy findings (a digestive tract filled with ingesta, contracted ventricles, dilated and blood-filled atria, lung congestion, and edema).

At day 33, five broilers were randomly selected from each pen and two blood samples from each were collected from the brachial vein. The first one was collected into heparinized tubes for the determination 
of red blood cells (RBCs), white blood cells (WBCs) and packed cell volume (PCV), as indicated by the standard procedures of Jain, (1986). Hemoglobin $\mathrm{Hb}$ ) was measured by a colorimetric technique as portrayed by Drabkin and Austin, (1932). The second blood sample was collected into non-heparinized tube which allowed to coagulate at room temperature for 3 $\mathrm{h}$, centrifuged at $3000 \mathrm{rpm}$ for $10 \mathrm{~min}$ to obtain sera. Sera samples were stored in Eppendorf vials at -20 ${ }^{\circ} \mathrm{C}$ for later biochemical analysis.

At the end of the experiment, an estimate was made of the income over feed cost (IOFC) in L.E/chick. This performed by estimation of revenue of average body weight and feeding cost per chick.

\section{Laboratory analysis}

Samples of starter, grower and finisher diets were ground to pass $1 \mathrm{~mm}$ screen (Cyclotec 1093, Foss Sweden). Following (AOAC, 2010) procedures, samples were analyzed for dry matter, ash, crude fat (Soxhlet procedure; method 2003.05) and crude protein (Kjeldahl procedure; method 2001.11). Acid detergent fiber was determined according to the procedure described by (Van Soest et al., 1991) with modifications for use in the $\mathrm{ANKOM}^{2000}$ fiber analyzer apparatus (ANKOM Technology Cooperation, Fairport, NY, USA). The values of metabolizable energy were determined according to (NRC, 1994) based on nutrient analyses. Chemical analysis was performed in international accredited (ISO 17025) lab (Feed, Water and Food of Animal Origin Analysis Lab, Veterinary Medicine, Kafrelsheikh University).

\section{Biochemical Assays}

Serum total protein, albumin and globulin values were determined according toTrinder (1969), serum total cholesterol (Naito and David, 1984), serum level of triglyceride (Fossati and Prencipe, 1982) and serum high density lipoprotein (HDL) (Grove, (1979) utilizing enzymatic packs from Quimica Clinica Aplicada S.A. (Amposta, Spain). Very low density lipoprotein (VLDL) was calculated using the formula of Friedewald et al. (1972). The activities of alanine and aspartate aminoaminotransferases (ALT and AST) were assayed by the combined methods of Bergmeyer et al. (1976) using commercial assay kits (Diamond Diagnostics, Egypt).

\section{Statistical analyses}

Statistical analyses were performed by using software package (Minitab 15 Statistical Software English). All data were tested for distribution normality and homogeneity of variance. 2-sample $t$ (test and confidence interval) test was used to compare the differences between groups during study period. A value of $\mathrm{P}<0.05$ was considered statistically significant.

\section{RESULTS}

The statistical analyses indicated that body weight was significantly decreased in restricted broilers (Table 2). Feed intake was nearly similar in all groups, while feed efficiency was significantly lower in restricted broilers. Restricted broilers showed significant low rates of total mortality and sudden death syndrome (SDS) as shown in Table 2.

Table 2: Effect of early feed restriction on broilers performance and mortality rate (\%).

\begin{tabular}{cll}
\hline Item & Ad-libitum & Early feed restriction $^{\mathrm{a}}$ \\
\hline Initial weight $(\mathrm{g})$ & $37.5 \pm 0.75$ & $37.2 \pm 0.8$ \\
\hline Final body weight $(\mathrm{g})$ & $1920^{\mathrm{a}} \pm 50$ & $1730^{\mathrm{b}} \pm 40$ \\
\hline Body weight gain $(\mathrm{g})$ & $1882^{\mathrm{a}} \pm 48$ & $1693^{\mathrm{b}} \pm 39$ \\
\hline Feed intake $(\mathrm{Kg})$ & $3.32 \pm 0.08$ & $3.29 \pm 0.09$ \\
\hline Feed conversion ratio & $1.75^{\mathrm{a}} \pm 0.2$ & $1.89^{\mathrm{b}} \pm 0.3$ \\
\hline Total mortality rate $(\%)$ & $3.86^{\mathrm{a}} \pm 0.01$ & $2.9^{\mathrm{b}} \pm 0.03$ \\
\hline Sudden death syndrome $(\%)$ & $2.2^{\mathrm{a}} \pm 0.01$ & $0.72^{\mathrm{b}} \pm 0.01$ \\
\hline
\end{tabular}

a $20 \%$ feed restriction between 7-21 days.

Means with different superscript are significantly different $(\mathrm{P}<0.05)$

From the economy point of view, restricted broilers showed a significant lower income over feed cost than those fedad libitum (Table 3). The economic difference was due to the lower body weight of restricted broilers at the marketing age.

The present study showed that early feed restriction had no significant effect on serum ALT, AST, proteins, albumin, globulins, HDL, VLDL and cholesterol (Table 4), While, restricted broilers had significantly decreased serum triglycerides and total lipids than those fed ad libitum diet. There was a significant decreased in RBCs and WBCs number, $\mathrm{PCV}$ and $\mathrm{Hb}$ concentration in restricted broilers (Table 5). 
Assiut Vet. Med. J. Vol. 61 No. 147 October 2015

Table 3: Effect of early feed restriction on income over feed cost of broiler chickens (LE/chick).

\begin{tabular}{lll}
\hline Item & Ad-libitum & Early feed restriction \\
\hline Revenue & $24.96^{\mathrm{a}} \pm 0.8$ & $22.49^{\mathrm{b}} \pm 0.7$ \\
\hline Feed cost & $11.82 \pm 0.6$ & $11.71 \pm 0.8$ \\
\hline IOFC & $13.15^{\mathrm{a}} \pm 0.7$ & $10.79^{\mathrm{b}} \pm 0.7$ \\
\hline Relative IOFC, $\%$ & $100^{\mathrm{a}} \pm 5.3$ & $82.05^{\mathrm{b}} \pm 5.3$ \\
\hline
\end{tabular}

${ }^{\mathrm{a}} 20 \%$ feed restriction between $7-21$ days; IOFC, income over feed cost.

Means with different superscript are significantly different $(\mathrm{P}<0.05)$.

Live weight price was $13 \mathrm{LE} / \mathrm{kg}$; mean broiler feed (starter, grower and finisher) price was $3.56 \mathrm{LE} / \mathrm{kg}$.

Table 4: Effect of early feed restriction on serum biochemical parameters of broiler chickens.

\begin{tabular}{lll}
\hline Item & Ad-libitum & Early feed restriction $^{\mathrm{a}}$ \\
\hline Alanine aminotransferase $(\mathrm{u} / \mathrm{l})$ & $43.0 \pm 6.7$ & $39.57 \pm 3.7$ \\
\hline Aspartate aminotransferase $(\mathrm{u} / \mathrm{l})$ & $35.7 \pm 3.1$ & $40.84 \pm 6.1$ \\
\hline Total proteins $(\mathrm{g} / \mathrm{dl})$ & $4.06 \pm 0.52$ & $3.25 \pm 0.35$ \\
\hline Albumin $(\mathrm{g} / \mathrm{dl})$ & $1.45 \pm 0.19$ & $1.21 \pm 0.16$ \\
\hline Globulin $(\mathrm{g} / \mathrm{dl})$ & $2.61 \pm 0.47$ & $2.03 \pm 0.42$ \\
\hline Total lipids $(\mathrm{mg} / \mathrm{dl})$ & $402.2^{\mathrm{a}} \pm 6.9$ & $381.1^{\mathrm{b}} \pm 3.2$ \\
\hline Triglycerides $(\mathrm{mg} / \mathrm{dl})$ & $54.14^{\mathrm{a}} \pm 4.2$ & $46.1^{\mathrm{b}} \pm 3.7$ \\
\hline Cholesterol $(\mathrm{mg} / \mathrm{dl})$ & $79.59 \pm 1.1$ & $78 \pm 3.8$ \\
\hline High density lipoprotein & $39.22 \pm 1.8$ & $44.5 \pm 4.9$ \\
\hline Very low density lipoprotein & $12.63 \pm 0.61$ & $13.13 \pm 0.91$ \\
\hline
\end{tabular}

${ }^{a} 20 \%$ feed restriction between 7-21 days

Means with different superscript are significantly different $(\mathrm{P}<0.05)$.

Table 5: Effect of early feed restriction of broiler diet on hematology.

\begin{tabular}{ccc}
\hline Item & Ad-libitum & Early feed restriction $^{\mathrm{a}}$ \\
\hline Hemoglobin $(\mathrm{g} / \mathrm{dl})$ & $11.26^{\mathrm{a}} \pm 0.19$ & $10.1^{\mathrm{b}} \pm 0.14$ \\
\hline $\mathrm{RBCs} * 10^{6} / \mathrm{mm}^{3}$ & $2.17^{\mathrm{a}} \pm 0.04$ & $1.97^{\mathrm{b}} \pm 0.05$ \\
\hline $\mathrm{TLC} * 10^{3} / \mathrm{ml}$ & $30.8^{\mathrm{a}} \pm 1.9$ & $20.52^{\mathrm{b}} \pm 1.0$ \\
\hline $\mathrm{PCV} \%$ & $35.65^{\mathrm{a}} \pm 2.5$ & $28.28^{\mathrm{b}} \pm 1.8$ \\
\hline
\end{tabular}

${ }^{a} 20 \%$ feed restriction between 7-21 days; RBCS, red blood corpuscles; TLC, total leukocytes count; PCV, packed cell volume.

Means with different superscript are significantly different $(\mathrm{P}<0.05)$.

\section{DISCUSSION}

In this study, growth rate could not be sustained with $20 \%$ feed restriction as found by Pinchasov and Jensen (1989) who stated that feed restriction can exert negative effects on the body weight at marketing age. Also, Fattori et al. (1991) indicated the ineffectiveness of feed restriction in broiler chickens. An experiment conducted by $\mathrm{Yu}$ et al. (1990) on chicks in which restriction started from 7 to
$14 \mathrm{~d}$, reported that after refeeding ad libitum, no compensatory growth was observed. Makinde, (2012) reported that feed restriction negatively affected growth performance as the severity of restriction increased. Recently, Shabani et al. (2015) concluded that the feed restriction for 7 or 14 days seemed to be insufficient to markedly improve the feed conversion ratio of broiler chickens at the end of the study (at 42 day of age). On the other hand, Zhan et al. (2007) and Onbasilar et al. (2009) reported that in re-feeding 
period from 22 day of age till the end of the experiments (63 and $42 \mathrm{~d}$, respectively), growth parameters were not statistically significant.

$20 \%$ feed restriction from 7 to 21 days significantly reduced total mortalities and SDS in broiler chickens. Similarly, Fontana (1992) and Yu (1992) observed that quantitative feed restriction reduced mortality rate in broiler chickens. Also, Bowes et al. (1988) showed that $25 \%$ feed restriction reduced SDS to $0 \%$, while in ad libitum feeding it was $3.33 \%$. A consistent result of early under-nutrition is reduction in the incidence of metabolic disorders and especially SDS (Leeson and Summers, 2008).

Results of the current study showed an adverse effect of feed restriction on economic return. Similarly, Nwachukwu and Ibe (1990) mentioned that $15 \%$ feed restriction had not an economic advantage over ad libitum feeding, while Makinde, (2012) reported that the revenue declined as the period of feed restriction increased. This ascertains the assumption that the faster the growth rate, the better the utilization of feed, since maintenance nutrient needs are minimized (Leeson and Summers, 2008).

Serum total lipids and triglycerides were lower in restricted broilers than those fed ad- libitum. It might be due to the obligate use of considerable levels of triglycerides for energy demand during feed restriction (Demir et al., 2004; Klasing, 1998).

The obtained data of hematology may be revealed to a folic acid deficiency as a result of the feed restriction as monitored by Maxwell et al. (1991) who indicated that the decrease in total leukocytes count in the feed-restricted broilers may be associated with a stress response.

In the current study restricted broilers failed to gain a compensatory growth in the re-feeding period (from 22 to 35 days). It might be due to the high maintenance requirements with advanced age. We did not feed broilers after 35 days because as the bird gets older, a greater proportion of nutrients are used for maintenance and less is used for growth. At 5 weeks old, $60 \%$ of energy directed to maintenance and $40 \%$ to growth requirement (Leeson and Summers, 2008). So, increasing period of feeding beyond 5 weeks decreases efficiency of feed utilization. Although feed restriction decreased mortality rate, it increased FCR leading to high feed cost. Also, this restriction was associated with anemia and low total leukocytes count. Therefore feed restriction is not recommended for the rapidly growing broiler chickens.

\section{CONCLUSION}

$20 \%$ feed restriction from 7 to 21 days of age adversely affected growth performance, blood parameters and income over feed cost. Therefore our results recommended ad libitum feeding for broiler chickens.

\section{REFERENCES}

AOAC, (2010): Association of Official Analytical Chemists, Official methods of analysis of the AOAC international (18th ed.).

Bergmeyer, H.U.; Bowers, G.N.; Horder, M. and Moss, D.W. (1976): IFCC method for aspartate aminoaminotransferase. Appendix B. Conditions for the measurement of the catalytic concentrations of reagent enzymes and the contaminants. Clinica chimica acta; international journal of clinical chemistry 70, F41-42.

Bowes, V.A.; Julian, R.J.; Julian, L.S.; Stirtzinger, L. and Stirtzinger, T. (1988): Effect of feed restriction on feed efficiency and incidence of sudden death syndrome in broiler chickens. Poult. Sci., 67(7): 1102-1104

Demir, E.; Sarica, S.; Sekeroglu, A.; Ozcan, M.A. and Seker, $Y$. (2004): Effects of early and latefeed restriction or feed withdrawal on growth performance, ascites and blood constituents of broiler chickens. Animal Sci. 54: 152-158, 2004.

Drabkin, D.L. and Austin, J.H. (1932): Spectrophotometric studies I. Spectrophotometric constants for common hemoglobin derivatives in human, dog, and rabbit blood. Journal of Biological Chemistry 98, 719-733.

Fattori, T.R.; Wilson, H.R.; Harms, R.H. and Miles, R.D. (1991): Response of broiler breeder females to feed restriction below recommended levels. 1. Growth and reproductive performance. Poult. Sci., 70: 2636.

Fontana, E.A.; Weaver, W.D.; Watkins, B.A. and Denbow, D.M. (1992): Effect of early feed restriction on growth, feed conversion and mortality in broiler chickens. Poult. Sci., 71: 1296-1305.

Fossati, P. and Prencipe, L. (1982): Serum triglycerides determined colorimetrically with an enzyme that produces hydrogen peroxide. Clinical chemistry 28, 2077-2080.

Friedewald, W.T.; Levy, R.I. and Fredrickson, D.S. (1972): Estimation of the concentration of low-density lipoprotein cholesterol in plasma, without use of the preparative ultracentrifuge. Clinical chemistry 18, 499-502.

Grove, T.H. (1979): Effect of reagent $\mathrm{pH}$ on determination of high-density lipoprotein cholesterol by precipitation with sodium phosphotungstate-magnesium. Clinical chemistry $25,560-564$.

Jain, N. (1986): The dog: normal hematology with comments on response to disease. Veterinary 
hematology, 4th edn. Lea \& Febiger, Philadelphia, 103-125.

Klasing, K.C. (1998): Comparative Avian Nutrition. Cab International Press, New York, USA.

Leeson, S. and Summers, J.D. (2008): Feeding programs for broiler chickens. Chapter 5, page 249, 257. Commercial poultry nutrition, 3rd edition, Nottingham University Press.

Makinde, O.A. (2012): Influence of timing and duration of feed restriction on growth and economic performance of finisher broiler chickens. African Journal of Food, Agriculture, Nutrition and development, volume 12 No.7 December, 2012.

Maxwell, M.H.; Robertson, G.W.; Anderson, I.A.; Dick, L.A. and Lynch, M. (1991): Haematology and histopathology of sevenweek-old broilers after early food restriction. Research in Veterinary Science, Volume 50, Issue 3, May 1991, Pages 290-297.

Meluzzi, A.; Primiceri, G.; Giordani, R. and Fabris, G. (1992): Determination of blood constituents reference values in broilers. Poultry science 71, 337-345.

Naito, H. and David, J. (1984): Laboratory considerations: determination of cholesterol, triglyceride, phospholipid, and other lipids in blood and tissues. Laboratory and research methods in biology and medicine 10,1 .

NRC, (1994): Nutrient Requirements of Poultry, 9th Ed. National Academy of Sciences-National Research Council, Washington, D.C.

Nwachukwu, E.N. and Ibe, S.N. (1990): Effects of Quantitative Feed Restriction on Broiler Growth and Monetary returns. Nigerian Journal of Animal Production 17: 10-13.

Onbasilar, E.E.; Yalcin, S.; Torlak, E. and Ozdemir, $P$. (2009): Effects of early feed restriction on liveperformance, carcass characteristics, meat and liver composition, some blood parameters, heterophile lymphocyte ratio, antibody production and tonic immobility duration. Trop. Anim. Health and Prod., 41: 1513-1519.
Pinchasov, Y. and Jensen, L.S. (1989): Comparison of physiological and chemical means of feed restriction in broiler chicks. Poult. Sci., 68: 61-69.

Plavnik, I. and Hurwitz, S. (1989): Effect of dietary protein, energy, and feed pelleting on the response of chicks to early feed restriction. Poultry science 68, 1118-1125.

Shabani, S.; Seidavi, A.; Asadpour, L. and Corazzin, M. (2015): Effects of physical form of diet and intensity and duration of feed restriction on the growth performance, Blood variables, microbial flora, immunity, and carcass and organ characteristics of broiler chickens. Available online 16 July 2015. In Press, Accepted Manuscript, Livestock Science.

Sahraei, M. (2014): Effects of feed restriction on metabolic disorders in broiler chickens: A review. Biotechnology in Animal Husbandry30, 1-13.

Trinder, P. (1969): Determination of blood glucose using an oxidase-peroxidase system with a non-carcinogenic chromogen. Journal of clinical pathology22, 158-161.

Van Soest, P.V.; Robertson, J. and Lewis, B. (1991): Methods for dietary fiber, neutral detergent fiber, and nonstarch polysaccharides in relation to animal nutrition. Journal of dairy science74, 3583-3597.

Yu, M.E. and Robinson, F.E. (1992): The application of short-term feed restriction to broiler chicken production: A review. J. Appl. Poult. Res., 1: 147-153.

Yu, M.E.; Robinson, F.E.; Clandini, M.T. and Bodnar, L. (1990): Growth and body composition of broiler chickens in response to different regimes of feed restriction. Poult.Sci., 69 (12): 2074-2081.

Zhan, X.A.; Wang, M.; Ren, H.; Zhao, R.Q.; Li, J.X. and Tan, Z.L. (2007): Effect of early feed restriction on metabolic programming and compensatory growth in broiler chickens. Poultry Science, 86: 654-660.

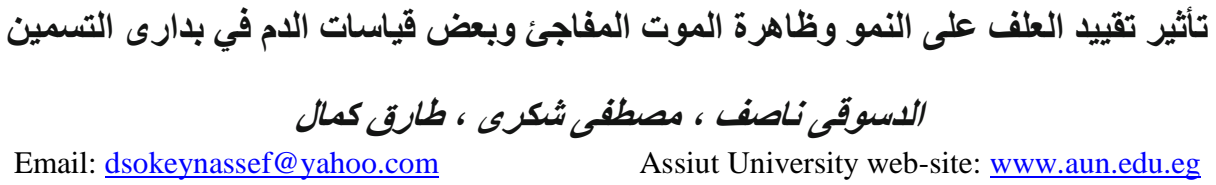

